\title{
Nelore females along a new Brazilian agricultural frontier: hematological and clinical-biochemical approaches
}

\author{
[Abordagens hematológicas e bioquímicas clínicas de fêmeas Nelore na nova \\ fronteira agrícola brasileira]
}

\author{
L.H.O. Tolentino ${ }^{1}$, M.L.D.L Tolentino ${ }^{2}$, J.B. Dantas ${ }^{2}$, S.S. Fonseca ${ }^{1}$, A.F.M. Vaz ${ }^{1 *}$ \\ ${ }^{1}$ Hospital Universitário Veterinário - Universidade Federal de Campina Grande - Patos, PB \\ ${ }^{2}$ Universidade Federal do Piauí - Bom Jesus, PI
}

\begin{abstract}
The Nelore breed is the second largest bovine breed in the world and has actively participated in the expansion of new Brazilian agricultural frontiers. In this context, the purpose of this study was to determine the hematological and biochemical reference intervals of healthy Nelore matrices raised under an extensive regime without supplementation along southwest of Piauí state. Blood samples were collected from fifty-five multiparous female of the Nelore breed. Biochemical and hematological parameters were analyzed using a parametric statistical method with 95\% CI of reference limits. The average values of red blood cells, hemoglobin as well as hematimetric indices showed reference ranges similar to reference standards. The hematocrit as well as granulocytes and agranulocytes presented alterations typical of animals raised in environments with higher temperatures. Mineral, enzymatic, protein and metabolic profiles were similar to other bovine breeds but with a narrower range of values. However, lower mean values were observed for levels of ionized calcium, total protein and urea. Nelore females present slightly different biochemical and hematological profiles from other breeds, which might result from the environmental and nutritional management applied and the natural deficiency of nitrogen, phosphorus and calcium in the region's pastures.
\end{abstract}

Keywords: cows, blood count, serum, bovine, livestock

\section{RESUMO}

Nelore é a segunda maior raça bovina do mundo e tem participado ativamente da expansão das novas fronteiras agrícolas brasileiras. Nesse contexto, o objetivo do presente estudo foi determinar os intervalos de referência hematológicos e bioquímicos de matrizes Nelore criadas em regime extensivo sem suplementação, ao longo do sudoeste do estado do Piauí. Amostras de sangue foram coletadas de 55 fêmeas multíparas da raça Nelore. Os parâmetros bioquímicos e hematológicos foram analisados por método estatístico paramétrico com IC 95\% para os limites de referência. Os valores médios de hemácias, hemoglobina e indices hematimétricos apresentaram intervalos de referência semelhantes aos padrões de referência. Tanto o hematócrito quanto os granulócitos e os agranulócitos apresentaram alterações típicas de animais criados em ambientes com temperaturas mais elevadas. Os perfis mineral, enzimático, proteico e metabólico foram semelhantes aos de outras raças bovinas, mas com uma faixa de valores mais estreita. No entanto, valores médios mais baixos foram observados para os níveis de cálcio ionizado, proteína total e ureia. Fêmeas Nelore apresentam perfis bioquímicos e hematológicos ligeiramente diferentes de outras raças, o que pode resultar dos manejos ambiental e nutricional aplicados e da deficiência natural de nitrogênio, fósforo e cálcio nas pastagens da região.

Palavra-chave: vacas, contagem sanguínea, soro, bovino, pecuária

\section{INTRODUCTION}

Cattle farming is one of the main commodities of Brazilian agribusiness and the Nellore breed has

Recebido em 31 de janeiro de 2021

Aceito em 5 de maio de 2021

*Autor para correspondência (corresponding author)

E-mail: antonio.melo@ufcg.edu.br played an active role in this segment by spreading throughout the country, mainly due to its potential in the reproductive and beefproduction areas (Pesquisa..., 2019). In the center-north region of Brazil, in the decade of 2010, several socioeconomic transformations linked to the expansion of road infrastructure, 
logistics and energy, gave rise to expansion poles in the agricultural frontier based on the adoption of high-productivity farming technologies (Lopes, 2014). The expansion of the Nellore breed in this new agricultural frontier is notorious, to the detriment of traditional breeds in this region, such as the Curraleiro breed. Therefore, research to prove the herd's adaptability to new climatic, infectious, parasitic and botanical variants has been requested (Oliveira, 2002).

In veterinary clinical medicine, before defining physical and laboratory criteria for pathologies, one must investigate the health parameters. However, there is difficulty in interpreting reference data, whether applied to the herd or to individuals, due to the fact that there is great variability according to breed, age, aptitude, food management, climate and physiological state (González and Silva, 2017). The Clinical Laboratory Standard Institute defines a reference range as the set of results obtained by quantitative observation or measurement of an analyte in a selected group of individuals based on well-defined criteria. This requires specific reference ranges for each species, breed, sex, age and habitat where the animals live.

For bovine matrices, a large part of the clinical laboratory data has been obtained in animals with metabolic (Barreto et al., 2011) and infectious diseases (Almeida et al., 2010), so studies to establish reference ranges are scarce (Benesi et al., 2003). Given the scientific importance that reference intervals have in veterinary medicine by precisely enabling the individual clinical evaluation of animals, as well as the monitoring of nutritional and metabolic conditions in herds, this study aimed to determine the hematological and biochemical laboratory reference intervals of multiparous matrices of the Nelore breed raised under extensive management along the new Brazilian agricultural frontier.

\section{MATERIAL AND METHODS}

The collections of whole blood were performed at the Alvorada do Gurgueia Experimental Farm of the Federal University of Piauí (UFPI), in the municipality of Alvorada do Gurgueia, Latitude

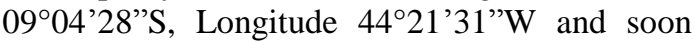
after sent to the Laboratory of Clinical Veterinary Pathology (LPCV/UFPI), located in the municipality of Bom Jesus - Piauí. The region was in the rainy season during the months of January to March 2019, the period in which the collections were made. The research project was previously submitted and authorized by the Research Ethics Committee of the Federal University of Piauí, under protocol number 512/2018.

Fifty-five multiparous adult females of the Nelore breed were used, with average weight of $418 \pm 36 \mathrm{~kg}$ and age, $36 \pm 3.8$ months. Matrices selection criteria excluded animal clinically exposed to the periparturient period, matrices in lactating, as well as animals not considered healthy by a veterinarian exam. The level of health was verified through clinical examinations according to Dirksen et al. (1993). The animals were maintained under extensive management and fed on native pasture composed of Stylosanthes spp. and Andropogon (Gayanus Kunth), water ad libitum, and had received vermifuge and vaccination in January and June 2018. It was decided to analyze the female profile due to the fact that a reference that takes sex into account becomes more reliable, since bovine males and females have different physiology.

Blood samples were collected by puncture of the coccygeal vein after physical containment of the animal and local disinfection with iodized alcohol. A $5.0 \mathrm{~mL}$ collection was performed in a tube (BD Vacutainer®, Becton Dickinson, Juiz de Fora, Brazil) containing ethylenediaminetetraacetic acid (EDTA) for hematological analysis, which consisted of hematimetry and leukometry. The samples were stored and transported under refrigeration for analysis at LPCV/UFPI. The variables evaluated in the $\mathrm{CBC}$ were performed with the aid of a Neubauer chamber for cell counting, the hemoglobin dosage was performed in semiautomatic equipment (Tekna T 300 Vet, Belo Horizonte, Brazil) using the cyanmethemoglobin method (Labtest Vet, Minas Gerais, Brazil) and the hematocrit value (\%) was obtained by microcentrifuge rotation at $2,604 \mathrm{~g}$ for 5 minutes. The hematocrit indices of Mean corpuscular volume (MCV), Mean corpuscular hemoglobin $(\mathrm{MCH})$ and Mean corpuscular hemoglobin concentration (MCHC) were calculated according to Weiss and Wardrop (2011). The differentiation of leukocytes was performed through blood smear using the Romanowsky 
method (quick panoptic kit) with the aid of an automatic cell counter for leukocyte differentiation, and the cells were counted and analyzed by immersion optical microscopy $(100 \times)$.

Blood samples of a $5.0-\mathrm{mL}$ volume were collected in microtubes without anticoagulant. Then, the blood was subjected to the centrifugation process (centrifuge model 90-1, Coleman Equipment for Laboratory Com. and Imp. Ltda, Brazil) to obtain the serum, which was then stored in a vertical freezer at $-20{ }^{\circ} \mathrm{C}$ until measurement of the variables. Biochemical analysis was performed by means of an automated Cobas C111 biochemical apparatus (Roche, Germany) using spectrophotometry in enzymatic or colorimetric kinetic assays when using the manufacturer's commercial biochemical kits to measure Albumin (ALB),
Total Protein (TP), Aspartate Aminotransferase (AST), Gamma Glutamyl Transferase (GGT), Alkaline Phosphatase (ALP), Creatine Kinase (CK), Lactate Dehydrogenase (LDH), Urea, Creatinine, Glucose, Cholesterol and Triglycerides, Total Calcium and Phosphorus. The fraction of Globulin (GLO) was calculated using GLO = TP - ALB. The electrolytic analysis was performed in an automated analyzer for electrolytes (Max Ion - Medmax, China) by the direct ion selectivity method for sodium, potassium, chlorine and ionized calcium. The analytical method of each parameter and the corresponding quality laboratory assay are reported in Table 1. Each parameter was tested for accuracy and reliability using lyophilized serum (calibrator for automated systems C.F.A.S - 10759350 190, Roche ${ }^{1}$ ).

Table 1. Blood parameters and analytical methods

\begin{tabular}{lll}
\hline Parameter & Analytical method & Catalog number \\
\hline $\begin{array}{l}\text { Protein and energy markers } \\
\text { Total protein }\end{array}$ & Biuret reaction (colourimetry) & 04657586190 \\
Globulin & Calculated parameter & \\
Albumin & Albumin bromocresol green (BCG) method \\
Urea & UV kinetic (urease and glutamate dehydrogenase GLDH) & 04657357190 \\
Creatinine & Jaffe reaction (colourimetry) & 04657636190 \\
Glucose & Hexokinase, G6PDH & 05401755190 \\
Triglyceride & Enzymatic; glycerol-3-phosphate oxidase (GPO)-PAP & 04657527190 \\
Cholesterol & Enzymatic; cholesterol oxidase (CHOD)-PAP & 04657594190 \\
Conjugated bilirubin & Diazo method (Jendrassik) & 04718917190 \\
Total bilirubin & Diazo method & 05589134190 \\
Unconjugated bilirubin & Calculated parameter & 05795640190 \\
& & \\
Enzymes and hepatic markers & & \\
ALT & IFCC ${ }^{2}$ without pyridoxal-5-phosphate & \\
AST & IFCC without pyridoxal-5-phosphate & 04718569190 \\
ALP & IFCC liquid & 04657543190 \\
$\gamma$-GT & IFCC L-Gamma-glutamyl-3-carboxy-4-nitroanilide Substrate & 04657373190 \\
LDH & IFCC Lactate to Pyruvate (NADH) & 05401461190 \\
CK & IFCC UV & 05401674190 \\
&
\end{tabular}

Mineral

Ionized calcium ion-selective electrode (ISE) ${ }^{3}$

$\begin{array}{lll}\text { Total calcium } & \text { o-cresolphtalein complexone (colourimetry) } & 05061504190\end{array}$

$\begin{array}{llr}\text { Phosphorus } & \text { Phosphomolybdate } & \text { 05401780-190 }\end{array}$

Sodium ion-selective electrode (ISE) ${ }^{3}$

Potassium ion-selective electrode (ISE) ${ }^{3}$

Chlorine ion-selective electrode (ISE) ${ }^{3}$

${ }^{1}$ Roche Diagnostics Reagents for cobas ${ }^{\mathrm{TM}}$ c 111 Chemistry Analyzer; ${ }^{2}$ International Federation of Clinical Chemistry and Laboratory Medicine; ${ }^{3}$ Solution calibrator pack - A/B/Flush LBPK 500 Max Ion.

The Clinical and Laboratory Standards Institute (Defining..., 2008) procedure using GraphPad Prism 5.1 software was applied to estimate the reference range. The variables were submitted to normality analysis by the D'Agostino \& Pearson test with a 5\% significance level. Data considered normal were expressed as mean \pm standard deviation. Standard error and coefficient 
of variation for each parameter were also calculated. The reference interval was expressed representing the $95 \%$ confidence interval of the sample population.

\section{RESULTS}

Throughout the experiment, the parameters observed in the clinical examination remained within the reference limits for the bovine species. Moreover, there was no report of clinical hypocalcemia in peripartum period even with $a d$ libitum lactation demands. Regarding the data, a Gaussian distribution was observed which led to the use of parametric statistics to determine a range that expressed $95 \%$ of the sample population. The hematological erythrocyte values of Nellore matrices (Table 2) for red blood cells $\left(7.33 \pm 0.67 \times 10^{6} \mu \mathrm{L}\right)$, hemoglobin (120.16 $\pm 4.32 \mathrm{~g} / \mathrm{L})$, hematocrit $(36.52 \pm 31.31 \%)$, MCV (48.52 $\pm 3.77 \mathrm{fL} /$ cell), MCHC (33.50 \pm 3.07 $\mathrm{g} / \mathrm{dL}), \mathrm{MCH}(16.68 \pm 1.28 \mathrm{pg} /$ cell $)$ showed a reduced range and low coefficient of variation.

Table 2. Hematimetric values for Nellore matrices along a new Brazilian agricultural frontier

\begin{tabular}{ccccccc}
\hline & Red blood cells & Hemoglobin & Hematocrit & $\mathrm{MCV}^{1}$ & $\mathrm{MCHC}^{2}$ & $\mathrm{MCH}^{3}$ \\
\hline & $\mathrm{x} 10^{6} \mu \mathrm{L}$ & $\mathrm{g} / \mathrm{L}$ & $\%$ & $\mathrm{fL} / \mathrm{Cell}$ & $\mathrm{g} / \mathrm{dL}$ & $\mathrm{pg} / \mathrm{Cell}$ \\
Mean & 7.33 & 120.16 & 36.52 & 48.52 & 33.50 & 16.68 \\
$\mathrm{SD}$ & 0.67 & 4.32 & 3.31 & 3.77 & 3.07 & 1.28 \\
$\mathrm{SE}$ & 0.09 & 0.58 & 0.45 & 0.5131 & 0.41 & 0.17 \\
$\mathrm{CV}$ & 9.18 & 3.16 & 9.09 & 7.77 & 9.16 & 7.72 \\
$\mathrm{RR}$ & $7.15-7.52$ & $120.4-122.8$ & $35.61-37.42$ & $47.49-49.55$ & $32.66-34.34$ & $16.33-17.03$ \\
$\mathrm{R}^{*}$ & $4.90-7.50$ & $84.0-120.0$ & $21.00-30.00$ & $36.00-50.00$ & $38.00-43.00$ & $14.00-19.00$ \\
\hline
\end{tabular}

SD - Standard deviation; SE - Standard error; CV - Coefficient of variation (\%); RR - Reference range; ${ }^{1}$ Mean corpuscular volume; ${ }^{2}$ mean corpuscular hemoglobin concentration; ${ }^{3}$ mean corpuscular hemoglobin; * $\mathrm{R}$ - reference by Weiss and Wardrop (2011).

The total leukocytes $\left(11.08 \pm 2.13 \times 10^{3} / \mu \mathrm{L}\right)$, neutrophils $\left(5.03 \pm 1.55 \times 10^{3} / \mu \mathrm{L}\right)$, lymphocytes $\left(5.57 \pm 1.74 \times 10^{3} / \mu \mathrm{L}\right)$,
$\left(0.26 \pm 0.28 \times 10^{3} / \mu \mathrm{L}\right)$
and
eosinophils $\left(0.14 \pm 0.17 \times 10^{3} / \mu \mathrm{L}\right) \quad$ presented a higher coefficient of variation (Table 3 ).

Table 3. Absolute and relative leukocyte values for Nellore matrices along a new Brazilian agricultural frontier

\begin{tabular}{cccccccccc}
\hline & Leukocytes $^{\mathrm{a}}$ & Neutrophils & $\%$ & Lymphocytes & $\%$ & Monocytes & $\%$ & Eosinophils & $\%$ \\
\hline & $\mathrm{x} 10^{3} / \mu \mathrm{L}$ & $\mathrm{x} 10^{3} / \mu \mathrm{L}$ & & $\mathrm{x} 10^{3} / \mu \mathrm{L}$ & & $\mathrm{x} 10^{3} / \mu \mathrm{L}$ & & $\mathrm{x} 10^{3} / \mu \mathrm{L}$ & 0.14 \\
Mean & 11.08 & 5.03 & 45.11 & 5.57 & 50.04 & 0.26 & 2.87 & 2.02 \\
SD & 2.13 & 1.55 & 11.08 & 1.74 & 11.60 & 0.28 & 3.12 & 0.17 \\
SE & 0.29 & 0.21 & 1.50 & 0.23 & 1.57 & 0.39 & 0.42 & 0.24 & 0.40 \\
$\mathrm{CV}$ & 19.24 & 30.87 & 24.57 & 31.70 & 23.18 & 110.43 & 108.7 & 123.44 & 144.6 \\
$\mathrm{RR}$ & $10.50-11.66$ & $4.60-5.45$ & $42.1-48.1$ & $5.09-6.05$ & $46.8-53.2$ & $0.18-0.39$ & $2.0-3.7$ & $0.09-0.19$ & $1.2-2.8$ \\
R* & $6.40-8.60$ & $1.1-2.5$ & - & $3.10-4.90$ & - & $0.30-0.70$ & - & $0.5-1.9$ \\
\hline
\end{tabular}

${ }^{a}$ Basophilis mean $\leq 0.08 \times 10^{3} / \mu \mathrm{L}$; SD - Standard deviation; SE - Standard error; CV - Coefficient of variation (\%); RR - Reference range; * R - reference by Weiss and Wardrop (2011).

The minerals (Table 4) sodium (129.00 \pm 3.56 $\mathrm{mmol} / \mathrm{L})$, chlorine $(96.67 \pm 3.16 \mathrm{mmol} / \mathrm{L})$, potassium $(4.69 \pm 0.82 \mathrm{mmol} / \mathrm{L})$, ionized calcium $(0.70 \pm 0.09 \mathrm{mmol} / \mathrm{L}), \quad$ total calcium $(2.85 \pm 0.56 \mathrm{mmol} / \mathrm{L})$ and phosphorus $(2.56 \pm 0$. $44 \mathrm{mmol} / \mathrm{L}$ ) as well as protein markers (Table 5), albumin $(35.19 \pm 2.97 \mathrm{~g} / \mathrm{dL})$, total proteins $(57.96 \pm 6.15 \mathrm{~g} / \mathrm{dL})$, globulins $(22.77 \pm 6.23 \mathrm{~g} / \mathrm{dL})$ presented reduced amplitude in the proposed ranges and low coefficient of variation.
The enzymatic and hepatic markers (Table 5), AST $(45.63 \pm 12.97 \mathrm{U} / \mathrm{L}), \quad \gamma-\mathrm{GT} \quad(18.00 \pm 11.22$ $\mathrm{U} / \mathrm{L}), \quad$ ALP $\quad(159.50 \pm 168.70 \quad \mathrm{U} / \mathrm{L}), \quad$ CK (143.00 \pm 190$)$, LDH $(1,137 \pm 939.50 \mathrm{U} / \mathrm{L})$, total bilirubin $\quad(1.14 \pm 0.43 \mu \mathrm{mol} / \mathrm{L}), \quad$ conjugated bilirubin $(0.91 \pm 0.49 \mu \mathrm{mol} / \mathrm{L})$, and nonconjugated bilirubin $(0.58 \pm 0.25 \mu \mathrm{mol} / \mathrm{L})$ as well as metabolic energy markers (Table 6), urea $(5.22 \pm 1.84 \mathrm{mmol} / \mathrm{L})$, creatinine $(107.84 \pm 26.33$ $\mu \mathrm{mol} / \mathrm{L}), \quad$ glucose $\quad(3.20 \pm 0.97 \quad \mathrm{mmol} / \mathrm{L})$, triglycerides $(0.21 \pm 0.08 \mathrm{mmol} / \mathrm{L})$, and total cholesterol $(5.11 \pm 7.43 \mathrm{mmol} / \mathrm{L})$ showed a high coefficient of variation. 
Table 4. Serum mineral concentrations for Nelore matrices along a new Brazilian agricultural frontier

\begin{tabular}{ccccccc}
\hline Sodium & $\begin{array}{c}\text { Chlorine } \\
\mathrm{mmol} / \mathrm{L}\end{array}$ & $\begin{array}{c}\text { Potassium } \\
\mathrm{mmol} / \mathrm{L}\end{array}$ & $\begin{array}{c}\mathrm{I}^{1} \mathrm{Ca}^{+2} \\
\mathrm{mmol} / \mathrm{L}\end{array}$ & $\begin{array}{c}\mathrm{T}^{2} \mathrm{Ca}^{+2} \\
\mathrm{mmol} / \mathrm{L}\end{array}$ & $\begin{array}{c}\text { Phosphorus } \\
\mathrm{mmol} / \mathrm{L}\end{array}$ \\
\hline Mean & 129.00 & 96.67 & 4.69 & 0.70 & 2.85 & 2.56 \\
$\mathrm{SD}$ & 3.56 & 3.16 & 0.82 & 0.09 & 0.56 & 0.44 \\
$\mathrm{SE}$ & 0.48 & 0.43 & 0.11 & 0.01 & 0.07 & 0.06 \\
$\mathrm{CV}$ & 2.77 & 3.27 & 17.49 & 13.47 & 19.91 & 17.34 \\
$\mathrm{RR}$ & $128.0-129.9$ & $95.81-97.54$ & $4.47-4.92$ & $0.68-0.73$ & $2.70-3.01$ & $2.44-2.68$ \\
$\mathrm{R}^{*}$ & $132.0-152.0$ & $97.0-111.0$ & $3.90-5.80$ & $0.94-1.31^{* *}$ & $2.43-3.10$ & $1.81-2.10$ \\
\hline
\end{tabular}

SD - Standard deviation; SE - Standard error; CV - Coefficient of variation (\%); RR - Reference range; ${ }^{1}$ Ionized calcium; ${ }^{2}$ Total calcium; * R - reference by Kaneko et al. (2008); **Lincoln and Lane (1990).

Table 5. Protein, enzymes and hepatic markers for Nellore matrices along a new Brazilian agricultural frontier

\begin{tabular}{ccccccccc}
\hline & & Total & Total globulin & & & & & \\
& Albumin & protein & & & AST & $\gamma$-GT & ALP & CK \\
\hline & g/L & g/L & g/L & U/L & U/L & U/L & U/L & U/L \\
Mean & 35.19 & 57.96 & 22.77 & 45.63 & 18.00 & 159.50 & 143.00 & 1,137 \\
SD & 2.97 & 6.15 & 6.23 & 12.97 & 11.22 & 168.70 & 190.90 & 939.50 \\
SE & 0.40 & 0.83 & 0.84 & 1.76 & 1.52 & 22.96 & 25.98 & 127.80 \\
CV & 8.46 & 10.62 & 27.39 & 28.43 & 62.33 & 105.76 & 133.52 & 82.66 \\
RR & $34.3-36.0$ & $56.2-59.6$ & $21.08-24.48$ & $42.09-49.17$ & $14.94-21.96$ & $113.50-205.50$ & $90.89-195.10$ & $880.10-1,393$ \\
$R^{*}$ & $30.3-35.5$ & $67.4-74.6$ & $30.0-34.8$ & $78.0-132.0$ & $6.10-17.4$ & $0-488.0$ & $2.40-23.40$ & $692.0-1,445$ \\
\hline
\end{tabular}

SD - Standard deviation; SE - Standard error; CV - Coefficient of variation (\%); RR - Reference range; * R reference by Kaneko et al. (2008).

Table 6. Metabolic energy and hepatic markers for Nellore matrices along a new Brazilian agricultural frontier

\begin{tabular}{ccccccccc}
\hline & Urea & Creatinine & Glucose & Triglycerides & $\begin{array}{c}\text { Total } \\
\text { Cholesterol }\end{array}$ & $\begin{array}{c}\text { Total } \\
\text { bilirubin }\end{array}$ & $\begin{array}{c}\text { Conjugated } \\
\text { bilirubin }\end{array}$ & $\begin{array}{c}\text { Unconjugated } \\
\text { bilirubin }\end{array}$ \\
\hline & $\mathrm{mmol} / \mathrm{L}$ & $\mu \mathrm{mol} / \mathrm{L}$ & $\mathrm{mmol} / \mathrm{L}$ & $\mathrm{mmol} / \mathrm{L}$ & $\mathrm{mmol} / \mathrm{L}$ & $\mu \mathrm{mol} / \mathrm{L}$ & $\mu \mathrm{mol} / \mathrm{L}$ & $\mu \mathrm{mol} / \mathrm{L}$ \\
$\mathrm{Mean}$ & 5.22 & 107.84 & 3.20 & 0.21 & 5.11 & 1.14 & 0.91 & 0.58 \\
$\mathrm{SD}$ & 1.84 & 26.33 & 0.97 & 0.08 & 7.43 & 0.43 & 0.49 & 0.25 \\
$\mathrm{SE}$ & 0.25 & 3.58 & 0.13 & 0.01 & 1.01 & 0.06 & 0.06 & 0.03 \\
$\mathrm{CV}$ & 35.36 & 24.3 & 30.28 & 41.59 & 145.23 & 38.02 & 54.41 & 43.61 \\
$\mathrm{RR}$ & $4.71-5.72$ & $100.77-114.92$ & $2.94-3.47$ & $0.18-0.23$ & $3.09-7.14$ & $0.85-1.19$ & $0.68-1.02$ & $0.51-0.65$ \\
$\mathrm{R} *$ & $7.14-10.7$ & $88.4-177.0$ & $2.50-4.16$ & $0-0.20$ & $2.07-3.11$ & $0.17-8.55$ & $0.68-7.52$ & 0.51 \\
\hline
\end{tabular}

SD - Standard deviation; SE - Standard error; CV - Coefficient of variation; RR - Reference range; * R - reference by Kaneko et al. (2008).

\section{DISCUSSION}

The values of red blood cells, as well as hemoglobin, MCV, MCHC, MCH, corroborate the values found by Weiss and Wardrop (2011) for beef cattle raised at milder temperatures. Compared to other matrices, such as the Jersey (Birgel et al., 2001) and Sindi (Silva et al., 2005) breeds, the values were similar. Hematocrit, however, was high and may indicate a contraction in volume due to the higher temperatures in the region (Ferreira et al., 2009) despite the supply of green pastures and water $a d$ libitum. The bovines present an inversion of the leukocyte formula until the 30th day of life (Biondo et al., 1998), for this reason they were selected for the study only before 2 months of age. A discrete difference in the leukocyte series, mainly in the lymphocyte population, compared to cattle located in Europe (Lorenz et al., 1978; Weiss and Wardrop, 2011) was observed, which can be attributed to the difference in management and especially temperature, which causes hot weather cattle to suffer thermal stress. 
This stress causes a serum increase in the cortisol hormone, which reduces lymphocyte values and increases neutrophil values by displacing them from the marginal compartment to the circulating compartment (Guyton and Hall, 2017).

All minerals remained within the reference ranges proposed by Kaneko et al. (2008), which analyzed cattle of various breeds kept in cold weather and of various aptitudes. However, ionized calcium, which is related to the clinical manifestation of diseases of the peripartum period and the functional status of the calcium metabolism of the cow, was found to be below the range recommended by Lincoln and Lane (1990). It is noteworthy that in the native pastures of the study region, calcium and phosphorus deficiency is common (Nascimento et al., 2005). Despite this, significant impacts on the total body stocks of these macrominerals were not observed. Cattle, in periods of deficiency, are able to remove up to $30 \%$ of the phosphorus deposited in bones, mainly vertebrae and ribs, which are cancellous bones (Vitti et al., 2000). Serum concentrations of calcium and phosphorus were correlated, with the ideal molar concentration of 1.6:1.0 $(\mathrm{Ca}+2: \mathrm{P})$ for productive cattle, possibly reaching up to 2.0:1.0 (Gonzaléz et al., 1998).

The albumin value remained similar to the reference range (Kaneko et al., 2008). However, in the case of total proteins and globulins, a reduction in body protein stocks was observed. Even if the raw protein deficiency in pastures in the rainy season is attenuated, the total nitrogen deficiency in native pastures of the region is significant (Almeida et al., 2002), which may result in limitations to the production and reproduction of more demanding breeds.

There was a similarity between AST and $\gamma$-GT obtained with the mean values of Nellore in extensive management (Fagliari et al., 1998). Serum AST has been used in the identification of severe and diffuse liver damage, especially when associated with jaundice (Gregory et al., 1999). Furthermore, AST can be useful in the diagnosis of neuro-muscular changes in animals (Kaneko et al., 2008). On the other hand, $\gamma$-GT, generally found on the outer surface of bile duct cells, has been correlated with serum overflow in hepatobiliary and cholestatic disorders (Hoffmann et al., 1989). Levels of ALP, which vary according to the age of the animal due to a bone isoenzyme that during growth phases remains high, was lower than that observed in calves of the Nellore $(439.63 \pm 132.06 \mathrm{U} / \mathrm{L})$ and Dutch $(415.93 \pm 114.62 \mathrm{U} / \mathrm{L})$ breeds according to Fagliari et al. (1998). However, it is similar to the serum activity of adult bovines between one and eight years of age of the Nellore breed (Fagliari et al. 1998). Although it is not a hepatospecific enzyme for bovines, it increases in cholangitis, biliary cirrhosis and bile duct obstruction (Anderson, 1992). High creatine kinase (CK) activity was verified when compared to that recommended by Kaneko et al. (2008). Since CK is present in higher concentration in skeletal muscle (Hoffmann et $a l ., 1989)$ there was an elevation in its levels due to extensive management, by displacement to graze. The mean $\mathrm{LDH}$, although little studied within the bovine profile, was within the ranges obtained by Kaneko et al. (2008).

Blood urea levels are affected by the nutritional level in ruminants and are a sensitive and immediate indicator of protein intake (Stockham and Scott, 2011). As already demonstrated, the low level of total nitrogen in pastures affected the level of total protein in animals as well as serum urea levels. Creatinine approximated the value found by Grünwaldt et al. (2005) for Aberdeen Angus and Criollo Argentino cattle. Plasma creatinine levels reflect the glomerular filtration rate, so high creatinine levels indicate a deficiency in renal function (Stockham and Scott, 2011). Serum glucose was found to be within the reference range (Kaneko et al., 2008) and although it is an insensitive marker of energetic status in cattle as it cannot by itself signal a negative energetic balance (Cozzi et al., 2011), it is still an important parameter to be analyzed in animals not supplemented for pregnancy and lactation. There have been few studies on lipid metabolism, although they denote the change in physiological status to which the matrixes are submitted. The cholesterol and triglyceride values were higher than the average cholesterol for cattle of the Curraleiro breed and mixed-breed heifers (Pogliani and Birgel Junior, 2007), as well as for cattle of various breeds kept in cold weather (Kaneko et al., 2008). The mean values of total, direct and indirect bilirubin, although little studied within the bovine profile, were lower than the intervals proposed by Kaneko et al. 
(2008). The determination of serum bilirubin has been valuable for the diagnosis of fatty liver in cows. In addition, total bilirubin rises after calving and during periods of anorexia (Mazzullo et al., 2014).

The reference ranges of hematological as well as biochemical parameters were quite reduced in amplitude, which can be attributed to the uniformity of the herd in terms of food management and environment. Moreover, sample collection being carried out at the same time and season and only with multiparous matrices contributed to this pattern. There was difficulty in direct comparison with other data in the literature, as most ruminant studies do not describe breed-specific reference intervals and suitability. This difficulty had already been described by Lepherd et al. (2009) and Souza et al. (2016).

\section{CONCLUSION}

The new Brazilian agricultural frontier presents climatic, infectious and botanical variants that are challenging for extensive livestock in more demanding categories of animals, as guaranteed by Nelore. Despite these contingencies, no changes were observed in their hematological and biochemical parameters that could negatively impact the health and reproductive potential of Nelore females. Therefore, the results should be considered important, as they aim to obtain specific reference values for the breed with great reproductive potential under an extensive management regime in a new Brazilian agricultural frontier without any energy or mineral supplementation.

\section{ACKNOWLEDGMENTS}

The authors thank University Veterinary Hospital (HVU) of the Federal University of Campina Grande (UFCG) for all the technical and instrumental support given to the study.

\section{REFERENCES}

ALMEIDA, K.S.; FREITAS, F.L.C.; TEBALDI, J.H. et al. Clinical, histopathological and enzymatic changes in sheep experimentally infected with Trypanosoma vivax. Ciênc. Anim. Bras., v.11, p.669676, 2010.
ALMEIDA, M.L.; RAMOS, R.S.; NASCIMENTO, H.T.S. et al. Proteína bruta, cálcio e fósforo em pastagem nativa de Campo Maior, PI. 2002. Available in: https://ainfo.cnptia.embrapa.br/digital/bitstream/item/4 4535/1/20.pdf. Accessed in: 14 June 2018.

ANDERSON, V.N. Veterinary gastroenterology. 2.ed. Philadelphia: Lea \& Febiger, 1992. 873p.

BARRETO JÚNIOR, R.A.; MINERVINO, A.H.H.; RODRIGUES, F.A.M.L. et al. Assessment of clinical and biochemical profile of cattle during induction and treatment of hypocalcemia. Braz. J. Vet. Res. Anim. Sci., v.48, p.192-199, 2011.

BENESI, F.J.; LEAL, M.L.R.; LISBOA, J.A.N. et al. Biochemical parameters to evaluate liver function of healthy female holstein calves during the first month of live. Ciênc. Rural, v.33, p.311-317, 2003.

BIONDO, A.W.; LOPES, S.T.A.; KOHAYAGAWA, A.; TAKAHIRA, R.K.; ALENCAR, N.X. Hemograma de bovinos (Bos indicus) sadios da raça Nelore no primeiro mês de vida, criados no estado de São Paulo. Ciênc. Rural, v.28, p.251-256, 1998.

BIRGEL JUNIOR, E.H.; ANGELINO, J.L.; BENESI, F.J.; BIRGEL, E.H. Reference values of the erythrogram of Jersey breed, raised in São Paulo state. Arq. Bras. Med. Vet. Zootec., v.53, p.1-9, 2001.

COZZI, G.; RAVAROTTO, L.; GOTTARDO, F. et al. Reference values for blood parameters in Holstein dairy cows: effects of parity, stage of lactation, and season of production. J. Anim. Sci., v.94, p.3895-3901, 2011.

DEFINING, establishing, and verifying reference intervals in the clinical laboratory; approved guidelines. 3.ed. Wayne, PA: CLSI, 2008. 76p.

DIRKSEN, G.; GRUNDER, H.D.; STOBER, M. Exame clínico dos bovinos. 3.ed. Rio de Janeiro Guanabara Koogan, 1993. 419p.

FAGLIARI, J.J.; SANTANA, A.E.; LUCAS, F.A. $e t$ al. Blood constituents of the newborn Nelore cattle (Bos indicus), Holstein cattle (Bos taurus), and Murrah buffalo (Bubalus bubalis). Arq. Bras. Med. Vet. Zootec., v.50, p.253-262, 1998.

FERREIRA, F.; CAMPOS, W.E.; CARVALHO, A.U. et al. Clinical, hematological, biochemical, and hormonal parameters of cattle submitted to heat stress. Arq. Bras. Med. Vet. Zootec., v.61, p.769-776, 2009.

GUYTON, A.C. e HALL J.E.- Tratado de Fisiologia Médica. Editora Elsevier. 13ª ed., 2017.

GONZÁLEZ, F.H.D.; OPINA, H.; BARCELLOS, J.O.J. Nutrição mineral em ruminantes. 2.ed. Porto Alegre: UFRGS, 1998. 
GONZÁLEZ, F.H.D.; SILVA, C.S. Introdução à bioquímica clínica veterinária. 3.ed. Porto Alegre: UFRGS, 2017. 358p.

GREGORY, L.; BIRGEL JUNIOR, E.H.; MIRANDOLA, R.M.S. et al. Reference values of the enzymatic activities of the aspartate aminotransferase and gamma glutamyltransferase of Jersey breed. The influence of age and sexual factors, and of the infection by the bovine leukosis virus. Arq. Bras. Med. Vet. Zootec., v.51, p.515-522, 1999.

GRÜNWALDT, E.G.; GUEVARA, J.C.; ESTÉVEZ, O.R. et al. Biochemical and haematological measurements in beef cattle in Mendoza plain rangelands (Argentina). Trop. Anim. Health Prod., v.37, p.527-540, 2005.

HALL, J.E.; GUYTON, A.C. Textbook of medical physiology. 12.ed. Philadelphia: Saunders Elsevier, 2011. 1120p.

HOFFMANN, W.E.; KRAMER, J.; MAIN, A.R.; TORRES, J.L. Clinical enzymology in the clinical chemistry of laboratory animals. New York: Pergamon Press, 1989. 1162p.

KANEKO, J.J.; HARVEY, J.W.; BRUSS, M.L. Clinical biochemistry of domestic animals. 6.ed. Burlington: Academic Press, 2008. 928p.

LEPHERD, M.L.; CANFIELD, P.J.; HUNT, G.B.; BOSWARD, K.L. Hematological, biochemical and selected acute phase protein reference intervals for weaned female Merino lambs. Aust. Vet. J., v.87, p.511, 2009.

LINCOLN, S.D.; LANE, V.M. Serum ionized calcium concentration in clinically normal dairy cattle, and changes associated with calcium abnormalities. J. Am. Vet. Med., v.197, p.1471-1474, 1990.

LOPES, M.A. Matopiba, a nova ousadia da agricultura brasileira, 2014. Available in http://www.infoteca.cnptia.embrapa.br/infoteca/handle /doc/1028673. Accessed in: 12 Jan. 2018.

LORENZ, R.J.; STRAUB, O.C.; DONELLY, W.J. et al. Comparative breed studies on the leukocytes parameters of several European cattle breeds as determined in national laboratories. J. Vet. Med. B, v.25, p.245-256, 1978.
MAZZULLO, G.; RIFICI, C.; LOMBARDO, S.F.; AGRICOLA, S. et al. Seasonal variations of some blood parameters in cow. Large Anim. Rev., v.20, p.81-84, 2014.

NASCIMENTO, H.T.S.; NASCIMENTO, M.P.S.C.B.; RIBEIRO, V.Q.; LEAL, J.A. Teores de cálcio e fósforo nos solos e pastagens nativas do MeioNorte brasileiro, 2005. Available in: http://ainfo.cnptia.embrapa.br/digital/bitstream/item/8 3513/1/CT1790001pdf. Accessed in: 12 Jan. 2018.

OLIVEIRA, J.H.F. Nelore: base genética e evolução seletiva no Brasil. Planaltina: Embrapa Cerrados, 2002. 54p

PESQUISA pecuária municipal. Rio de Janeiro: IBGE, $2019 . \quad$ Available in: https://sidra.ibge.gov.br/home/abate/brasil. Accessed in: 16 Feb. 2020.

POGLIANI, F.C.; BIRGEL JUNIOR, E. Reference values of the lipid profile of Holstein cattle bred in state of São Paulo. Braz. J. Vet. Res. Anim. Sci., v.44, p.373-383, 2007.

SILVA, R.M.N.; SOUZA, B.B.; SOUZA, A.P. et al. Effect of sex and age on physiologics and hematologics parameters of beef cattle Sindhi from semi-arid tropics. Ciênc. Agrotec., v.29, p.193-199, 2005.

SOUZA, B.C.; SENA, L.S.; LOUREIRO, D. et al. Determination of magnesium, chloride, calcium and phosphorus serum reference values for Dorper and Santa Inês sheep breeds. Braz. J. Vet. Res. Anim. Sci., v.36, p.167-173, 2016.

STOCKHAM, S.L.; SCOTT, M.A. Fundamentals of veterinary clinical pathology. 2.ed. New Jersey: Wiley-Blackwell, 2011. 928p.

VITTI, D.M.S.S.; KEBREAB, E.; ABDALLA, A.L. et al. A kinetic model of phosphorus metabolism in growing goats. Anim. Sci. J., v.78, p.2706-2712, 2000.

WEISS, D.J.; WARDROP, K.J. Schalm's veterinary hematology. 6.ed. New Jersey: John Wiley \& Sons, 2011. 1232p. 